\title{
PENGEMBANGAN LEMBAR KERJA PESERTA DIDIK (LKPD) BERBASIS INKUIRI TERBIMBING PADA MATERI TRANSFORMASI GEOMETRI
}

\author{
Marisa Indriani ${ }^{1}$, Choirun Niswah ${ }^{2}$, Sujinal Arifin ${ }^{3}$ \\ Universitas Islam Negeri Raden Fatah Palembang \\ E-mail: 1. indriani.marisa02@gmail.com \\ 2.niswah_c@yahoo.com \\ 3. sujinal@radenfatah.ac.id
}

\begin{abstract}
This research is a development research that aims to produce Student Worksheet (LKPD) based on Guided Inquiry on Geometric Transformation Material that is valid, practical and effective. The development procedure that used consists of: the preliminary stage (preparation and design phase) and the prototyping stage using the Formative Evaluation plot (expert reviews, one-to-one, small group and field test). The subjects of the experiments in this study were the students of grade XI IPA 1 MAN 1 Lahat. The result of this research showed that the LKPD based on Guided Inquiry on Geometry Transformation Material was valid, practical, effective. Expert reviews stage obtained valid LKPD result with a validity score of 4.07. One-to-one and small group stage obtained practical LKPD with a practicality score of 3,87 and 4,20.The effectiveness viewed from the workmanship of LKPD and post-test. Based on the results of LKPD workmanship, the value of all students were above KKM >60 and the result of post-test were obtained from the students' average score of 73.71 who belong to good categories and above the value of KKM > 60.
\end{abstract}

\begin{abstract}
ABSTRAK
Penelitian ini merupakan penelitian pengembangan yang bertujuan menghasilkan Lembar Kerja Peserta Didik (LKPD) berbasis Inkuiri Terbimbing pada Materi Transformasi Geometri yang valid, praktis dan efektif. Prosedur pengembangan yang digunakan terdiri dari tahap preminary (persiapan dan pendesainan) dan tahap prototyping menggunakan alur Formative Evaluation (expert reviews, one-to-one, small group dan field test). Subjek ujicoba dalam penelitian ini ialah peserta didik kelas XI IPA 1 MAN 1 Lahat. Hasil penelitian menunjukkan bahwa LKPD berbasis Inkuiri Terbimbing pada Materi Transformasi Geometri valid, praktis, efektif. Tahap expert reviews didapatkan hasil LKPD valid dengan skor kevalidan 4,07. Tahap one-to-one dan small group didapatkan LKPD praktis dengan skor kepraktisan 3,87 dan 4,20. Keefektifan dilihat dari hasil pengerjaan LKPD dan post-test. Dari hasil pengerjaan LKPD diperoleh nilai semua peserta didik pesera didik diatas KKM > 60 dan hasil posttest diperoleh rata-rata nilai peserta didik 73,71 yang termasuk kategori baik dan diatas nilai $\mathrm{KKM}>60$.
\end{abstract}

Kata kunci : Penelitian Pengembangan, Lembar Kerja Peserta Didik (LKPD), Transformasi Geometri. 


\section{PENDAHULUAN}

Kurikulum yang berlaku saat ini adalah kurikulum 2013 yang dalam pelaksanaannya menggunakan pendekatan Saintifik (Ilmiah). Dalam Permendikbud Nomor 22 Tahun 2016 tentang Standar Proses Pendidikan Dasar dan Menengah mengatakan, untuk memperkuat pendekatan Saintifik perlu diterapkan model pembelajaran berbasis penemuan, masalah, dan project. Salah satu strategi pembelajaran yang mengutamakan proses penemuan dalam kegiatan pembelajarannya untuk memperoleh pengetahuan adalah inkuiri (Jauhar, 2011:75).

Model pembelajaran berbasis penyelidikan (inkuiri) berpusat pada siswa. Inkuiri adalah strategi pembelajaran yang merangsang, mengajarkan dan mengajak siswa untuk berpikir kritis, analitis dan sistematis dalam rangka menemukan jawaban secara mandiri dari berbagai permasalahan yang diutarakan (Hartono, 2013:61). Hasil Penelitian Schlenker menunjukkan bahwa latihan inkuiri dapat meningkatkan pemahaman sains, produktif dalam berpikir kreatif, dan siswa menjadi terampil dalam memperoleh dan menganalisis informasi (Trianto, 2011:162). Selanjutnya Jauhar (2011:66) juga mengatakan, Standar Nasional Pendidikan Sains di Amerika Serikat menekankan agar semua pendidik dalam bidang sains pada jenjang pendidikan untuk menerapkan kegiatan berbasis inkuiri dalam kegiatan pembelajaran khususnya dalam bidang sains. Sehingga tepat jika inkuiri dijadikan sebagai salah satu model pembelajaran yang diterapkan dalam kurikulum 2013 di Indonesia.

Berdasarkan wawancara guru mata pelajaran Matematika kelas X MAN 1 Lahat diperoleh informasi bahwa guru belum pernah menggunakan model pembelajaran inkuiri dalam prose pembelajaran. Dalam angket pra-penelitian yang diisi oleh peserta didik juga menunjukkan $60,61 \%$ peserta didik tidak setuju bahwa mereka pernah mendengar pembelajaran Matematika berbasis Inkuiri.

Sebagaimana yang diungkapkan oleh Hartono (2013:72), adapun jenis inkuiri yang biasanya digunakan pada siswa yang belum pernah melakukan model inkuiri dalam proses pembelajaran adalah inkuiri terbimbing. Sehingga dalam proses penerapan pembelajaran inkuiri masih membutuhkan bimbingan yang banyak dari guru agar semua sintaks dalam inkuiri dapat tercapai dengan maksimal. Pada pendekatan inkuiri ini, guru banyak memberikan bimbingan pada tahap awal, pada tahap-tahap berikutnya bimbingan tersebut dikurangi sehingga siswa mampu melakukan proses inkuiri secara 
mandiri, bimbingan yang diberikan guru berupa pertanyaan-pertanyaan, petunjuk bagi peserta didik, dan membuat rumusan masalah (Hartono, 2013:69-72).

Beberapa hasil penelitian yang terkait, seperti: Dewi (2013:9) mengatakan bahwa hasil belajar dengan menggunakan pembelajaran berbasis inkuiri terbimbing lebih baik dari pada pembelajaran konvensional. Dalam penelitian lainnya, Lindawati (2011:16) mengatakan dengan menggunakan pembelajaran berbasis inkuri terbimbing dapat meningkatkan kemampuan pemahaman dan komunikasi matematis peserta didik. Sehingga penggunaan pembelajaran berbasis inkuiri terbimbing mempunyai dampak yang positif terhadap peserta didik. Penelitian oleh Winarsih (2014) mengatakan skor prestasi belajar peserta didik yang menggunakan LKS lebih tinggi dibandingkan yang tidak menggunakan LKS. Sehingga penggunakan Lembar Kerja Siswa (LKS) atau Lembar Kerja Peserta Didik (LKPD) dalam proses pembelajaran patut dipertimbangkan.

Lembar Kerja Peserta Didik atau LKPD merupakan nama lain dari Lembar Kerja Siswa atau LKS. Penggunaan kata LKPD disesuaikan dengan kurikulum 2013 yang berlaku saat ini. Dalam kurikulum 2013 revisi 2016, penyebutan kata "siswa" telah diganti menjadi "peserta didik". Lembar kerja peserta didik atau LKPD ini merupakan sarana kegiatan pembelajaran yang dapat membantu mempermudah pemahaman terhadap materi yang dipelajari.

Berdasarkan wawancara guru Matematika kelas X MAN 1 Lahat, salah satu bahan ajar yang biasanya digunakan oleh peserta didik ialah LKS atau LKPD. Namun penggunaan bahan ajar ini juga belum begitu optimal karena pada saat pelaksanaan pembelajaran masih ditemukan peserta didik yang kebingungan dalam mengerjakan soal-soal sesuai dengan langkah-langkah yang disampaikan pada LKPD, peserta didik juga sering kebingungan ketika dihadapkan pada soal-soal yang berbeda dengan soal yang dicontohkan oleh guru. Selain itu LKPD yang digunakan guru saat ini adalah LKPD yang dibeli dari penerbit. Padahal LKPD yang dibuat oleh penerbit belum tentu sesuai dengan karakteristik dan lingkungan peserta didik.

Untuk mengatasi permasalahan tersebut dibutuhkan LKPD dengan inovasi baru yaitu LKPD berbasis inkuiri terbimbing yang dibuat sendiri oleh guru yang bersangkutan. Sebagimana yang diungkapkan Prastowo (2014:203) bahwa LKPD dapat dibuat sendiri oleh guru yang bersangkutan. LKPD yang dibuat sendiri dapat lebih menarik serta sesuai dengan karakteristik peserta didik. Berdasarkan uraian tersebut, 
perlu dilakukan penelitian dan pengembangkan Lembar Kerja Peserta Didik (LKPD) berbasis inkuiri terbimbing materi Transformasi Geometri di MAN 1 Lahat.

Rumusan masalah dalam penelitian ini adalah "bagaimana langkah-langkah pengembangan Lembar Kerja Peserta Didik (LKPD) berbasis Inkuiri Terbimbing pada materi Transformasi Geometri di MAN 1 Lahat dan apakah Lembar Kerja Peserta Didik (LKPD) berbasis Inkuiri Terbimbing pada materi Transformasi Geometri di MAN 1 Lahat yang dikembangkan memenuhi kriteria valid, praktis dan efektif'. Tujuan penelitian adalah "mendeskripsikan langkah-langkah pengembangan Lembar Kerja Peserta Didik (LKPD) berbasis Inkuiri Terbimbing pada materi Transformasi Geometri di MAN 1 Lahat dan mengetahui kevalidan, kepraktisan dan keefektifan Lembar Kerja Peserta Didik (LKPD) berbasis Inkuiri Terbimbing pada materi Transformasi Geometri di MAN 1 Lahat yang dikembangkan.

\section{METODE PENELITIAN}

Penelitian ini adalah penelitian pengembangan yang bertujuan untuk menghasilkan Lembar Kerja Peserta Didik (LKPD) materi Transformasi Geometri berbasis Inkuiri Terbimbing yang valid, praktis dan efektif. Sintaks dari model pembelajaran inkuri terbimbing dimasukkan dalam lembar kerja peserta didik. Di dalam LKPD juga memuat bimbingan dan petunjuk kepada peserta didik untuk melakukan penyelidikan berdasarkan permasalahan-permasalahan yang diberikan dengan menggunakan konsep matematika dan menuntut siswa mengaplikasikan pengetahuan dan kemampuannya.

Subjek penelitian ini adalah Lembar Kerja Peserta Didik (LKPD) berbasis Inkuiri Terbimbing pada materi Transformasi Geometri dengan melibatkan pihak yang disebut sebagai subjek uji coba, yaitu peserta didik kelas XI IPA 1 MAN 1 Lahat.

\section{Prosedur Penelitian}

Prosedur penelitian ini terdiri dari dua tahap, yaitu tahap preliminary dan tahap prototyping yang menggunakan alur Formative Evaluation. Tahap preliminary terdiri dari tahap persiapan (analisis) dan pendesainan sedangkan tahap formative evaluation terdiri dari self evaluation, expert reviews, one-to-one, small group, dan field test. Tahap-tahap prosedur di atas dapat dijelaskan sebagai berikut.

\section{Tahap Preliminary}


Tahapan ini terdiri dari dua tahap, yaitu tahap persiapan dan tahap pendesainan. Pada tahap ini peneliti melakukan analisis peserta didik, analisis kurikulum, dan analisis materi. Informasi yang diperoleh pada tahap ini digunakan pada tahap pendesainan. Pada tahap pendesainan, peneliti melakukan pendesainan lembar kerja peserta didik materi Transformasi Geometri berbasis Inkuiri Terbimbing. Produk yang dihasilkan pada tahap ini berupa prototype awal.

\section{Tahap prototyping yang menggunakan alur Formative Evaluation}

Tahapan pada tahap Prototyping menggunakan alur Formative Evaluation, berikut alur formative evaluation dan penjelasannya yang merujuk pada pendapat Tessmer (1998).

Low Resistance to Revision $\longrightarrow$ High Resistance to Revision

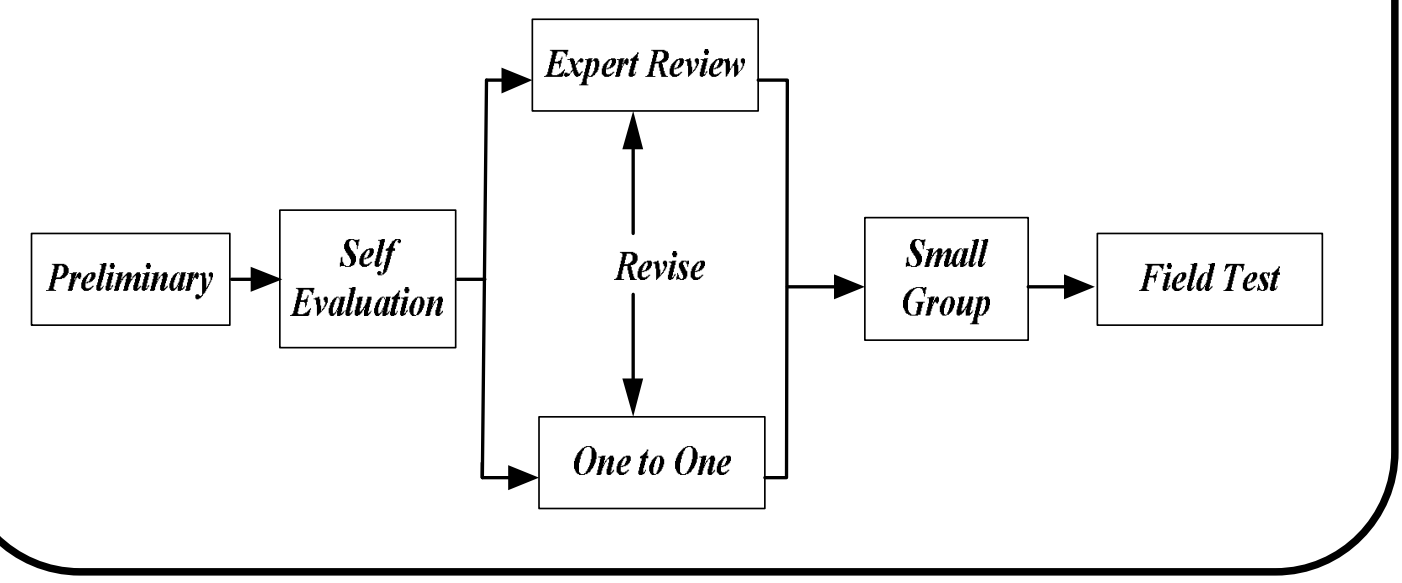

Gambar 1. Alur desain Formative Evaluation

a. Self Evaluation, pada tahap ini peneliti mengevaluasi sendiri prototype awal yang telah dikembangkan. Evaluasi yang dilakukan peneliti sebelumnya telah dikonfirmasikan kepada dosen pembimbing untuk perbaikan prototype awal.

b. Expert Review, prototype awal divalidasi oleh tiga orang pakar/ahli meliputi konten, konstruk dan bahasa. Skor yang diberikan pakar/ahli digunakan untuk menentukan kevalidan LKPD, komentar dan saran pakar/ahli digunakan untuk merevisi LKPD menjadi Prototype 1.

c. One-to-one, tahap ujicoba prototype 1 kepada tiga orang peserta didik dengan tingkatan kamampuan peserta didik tinggi, rendah dan sedang. Pemilihan peserta didik dilakukan dengan teknik purposive sampling. Pada tahap one-to-one akan 
diketahui tingkat kepraktisan dan respon peserta didik terhadap LKPD (prototype I). Komentar dan saran yang diberikan peserta didik digunakan juga untuk memperbaiki prototype I menjadi prototype II.

d. Small Group, prototype II hasil revisi pada tahap one-to-one diujicobakan pada kelompok kecil yang terdiri dari 8 orang peserta didik. Sebagaimana yang dijelaskan oleh Dick et al (dalam Ogle 2002 : 14), kelompok kecil terdiri dari 8 sampai 20 orang siswa yang memiliki karakteristik yang sama dengan karakteristik siswa yang akan dijadikan sasaran penelitian. Pemilihan peserta didik pada tahap ini juga dilakukan dengan teknik purposive sampling. Pada tahap small group akan diketahui tingkat kepraktisan dan respon peserta didik terhadap LKPD (prototype II). Komentar dan saran yang diberikan peserta didik digunakan juga untuk memperbaiki prototype II menjadi prototype III.

e. Field Test, pada tahap ini prototype III diujicobakan kepada subjek uji coba yaitu kelas XI IPA 1 MAN 1 Lahat. Evaluasi ini dilakukan terhadap produk pengembangan LKPD yang sudah selesai dikembangkan (prototype III) untuk mengetahui keefektifan dari produk LKPD yang telah dikembangkan.

Teknik pengumpulan data yang digunakan dalam peneltian ini adalah walkthrough, angket dan tes.

\section{Walkthrough}

Walkthrough digunakan untuk memvalidasi LKPD Transformasi Geometri berbasis Inkuiri Terbimbing yang dilakukan oleh para ahli/pakar yang meliputi ahli konten, konstruk dan bahasa pada tahap Expert Review. Selain digunakan untuk mengetahui kevalidan, walkthrough juga digunakan untuk merevisi prototype yang telah disusun. Saran dan komentar ahli/pakar pada tahap Expert Review digunakan untuk merevisi prototype I, sehingga akan menghasilkan prototype II LKPD Transformasi Geometri berbasis Inkuiri Terbimbing.

\section{Angket}

Angket diberikan kepada peserta didik pada tahap one-to-one dan small group setelah peserta didik selesai mengerjakan LKPD berbasis Inkuiri Terbimbing. Angket digunakan untuk mengetahui kepraktisan Lembar Kerja Peserta Didik (LKPD) pada materi Transformasi Geometri berbasis Inkuiri Terbimbing. Jenis 
angket yang digunakan dalam penelitian ini adalah angket tertutup dengan opsi jawaban menggunakan skala likert.

\section{Tes}

Tes dilakukan untuk mengetahui keefektifan Lembar Kerja Peserta Didik (LKPD) materi Transformasi Geometri berbasis Inkuiri Terbimbing yang telah peneliti kembangkan pada tahap fied test. Soal tes sebelumnya divalidasi terlebih dahulu sebelum diujicobakan. Tes yang dilakukan berupa post-test yaitu tes setelah penggunaan LKPD yang dikembangkan.

Data yang dikumpulkan dalam penelitian ini akan dilakukan analisis sebagai berikut.

\section{Walkthrough}

Walkthrouh dari ahli/pakar dianalisis secara deskriptif kualitatif. Komentar dan saran yang diberikan ahli/pakar akan dianalisis secara deskriptif. Selain dianalisis secara deskriptif kualitatif, untuk menentukan tingkat kevalidan bahan ajar ini, peneliti juga menggunakan penskoran pada walkthrouh yang dianalisis secara kuantitatif. Penskoran yang dilakukan menggunakan skala likert 5 dengan perhitungan srbagai berikut.

Skor Kevalidan $=\frac{\text { Jumlah jawaban validator }}{\text { jumlah butir }}$

Tabel 1. Klasifikasi Skor Kevalidan Bahan Ajar

\begin{tabular}{|c|c|}
\hline Skor & Kualitas Bahan Ajar \\
\hline$>4,20-5,00$ & Sangat valid \\
\hline$>3,40-4,20$ & Valid \\
\hline$>2,60-3,40$ & Kurang Valid \\
\hline$>1,80-2,60$ & Tidak Valid \\
\hline $1,00-1,80$ & Sangat Tidak Valid \\
\hline
\end{tabular}

(Modifikasi Widoyoko, 2013:112).

LKPD berbasis Inkuiri Terbimbing materi Transformasi Geometri dinyatakan valid jika skor yang diperoleh memenuhi kriteria valid dan sangat valid.

\section{Angket}

Perhitungan skor kepraktisan Lembar Kerja Peserta Didik (LKPD) materi Transformasi Geometri berbasis Inkuiri Terbimbing.

$$
\text { Skor Kepraktisan }=\frac{\text { Jumlah jawaban responden }}{\text { jumlah butir }}
$$


Tabel 2. Klasifikasi Skor Kepraktisan

\begin{tabular}{|c|c|}
\hline Skor & Kualitas Bahan Ajar \\
\hline$>4,20-5,00$ & Sangat Praktis \\
\hline$>3,40-4,20$ & Praktis \\
\hline$>2,60-3,40$ & Kurang Praktis \\
\hline$>1,80-2,60$ & Tidak Praktis \\
\hline $1,00-1,80$ & Sangat Tidak Praktis \\
\hline
\end{tabular}

(Modifikasi Widoyoko, 2013:112).

LKPD berbasis Inkuiri Terbimbing materi Transformasi Geometri dinyatakan praktis jika skor yang diperoleh memenuhi kriteria praktis dan sangat praktis.

Tes

Tes yang diberikan kepada peserta didik berupa post-test. Berikut perhitungan hasil belajar Lembar Kerja Peserta Didik (LKPD) materi Transformasi Geometri berbasis Inkuiri Terbimbing.

$$
\text { Hasil belajar }(\mathrm{X})=\frac{\text { jumlah skor yang diperoleh }}{\text { jumlah total maksimum }} \times 100
$$

Tabel 3. Kategori Hasil Belajar

\begin{tabular}{|c|c|}
\hline Ketuntasan & Klarifikasi \\
\hline $84<X \leq 100$ & Sangat Baik \\
\hline $69<X \leq 84$ & Baik \\
\hline $54<X \leq 69$ & Cukup Baik \\
\hline $39<X \leq 54$ & Kurang Baik \\
\hline $0<X \leq 39$ & Sangat Kurang Baik \\
\hline
\end{tabular}

(Modifikasi Arikunto, 2013: 281).

LKPD berbasis Inkuiri Terbimbing materi Transformasi Geometri dinyatakan praktis jika skor hasil belajar yang diperoleh memenuhi kriteria baik dan sangat baik.

\section{HASIL DAN PEMBAHASAN}

Produk yang dihasilkan dalam penelitian ini adalah Lembar Kerja Peserta Didik (LKPD) matematika materi Transformasi Geometri berbasis Inkuiri Terbimbing. Secara umum penelitian ini terdiri dari tahap priliminary (persiapan dan pendesaianan) dan tahap prototyping menggunakan alaur formative evaluation. Pada tahap persiapan, peneliti mengumpulkan informasi mengenai peserta didik MAN 1 Lahat untuk 
kebutuhan pendesaianan LKPD yang dikembangkan. Kurikulum yang digunakan di MAN 1 Lahat ialah kurikulum 2013 (K-13) revisi 2016. Berdasarkan silabus kurikulum 2013 (K-13) revisi 2016 peneliti memilih materi Transformasi Geometri meliputi Translasi dan Refleksi yang digunakan dalam penelitian ini. Penentuan materi ini berdasarkan pertimbangan dari peneliti, pembimbing dan guru MAN 1 Lahat.

Analisis materi dilakukan untuk mengetahui Kompetensi Inti (KI) dan Kompetensi Dasar (KD) pada materi Transformasi Geometri (Translasi dan Refleksi). Selanjutnya peneliti melakukan identifikasi KI dan KD tersebut, identifikasi dilakukan untuk melihat apakah KD pada materi yang bersangkutan tersebut dapat diterapkan pada pembelajaran berbasis Inkuiri Terbimbing. Berdasarkan hasil analisis KD diperoleh bahwa materi Transformasi Geometri (Translasi dan Refleksi dapat diterapkan pada LKPD berbasis Inkuiri Terbimbing. Informasi yang dperoleh pada tahap persiapan ini digunakan untuk kebutuhan pendesaianan LKPD. Produk yang dihasilkan pada tahap pendesainan disebu prototype awal.

Tahap prototyping menggunakan alur formative evaluation (self evaluation, expert review, one-to-one, small group, dan field test). Pada tahap self evaluation, peneliti melakukan evaluasi secara mandiri. Evaluasi yang dilakukan peneliti secara mendiri sebelumnya telah dikonfirmasikan kepada pembimbing. Hasil perbaikan pada tahap ini berupa prototype I dilanjutkan ke tahap Expert Review. Adapun perubahan LKPD yang terjadi pada tahap ini ialah pemberian langkah-langkah pada tahap pengumpulan data, pemberian peranyaan pada tahap kesimpulan dan penembahan daftar pustaka.

Pada tahap expert review, LKPD yang telah dievaluasi secara mandiri, pada tahap ini dinilai oleh tiga orang validator meliputi validasi konten, konstruk dan bahasa. Ketiga validator tersebut ialah Rieno Septra Nery, M.Pd, selaku dosen Universitas Negeri Islam (UIN) Raden Fatah Palembang, Rahma Siska Utari, M.Pd, selaku dosen Universitas Sjakhyakirti Palembang dan Mala Tumpuhara, S.Pd, selaku guru mata pelajaran matematika MAN 1 Lahat. Berdasarkan hasil analisis lembar walkthrough yang diisi, ketiga validator LKPD berbasis Inkuiri Terbimbing materi Transformasi Geometri dinyatakan valid dengan skor 4,07. Validator 1 menyatakan LKPD sangat valid dengan skor kevalidan 4,52, validator 2 menyatakan valid dengan skor kevalidan 3,74 dan validator 3 juga menyatakan valid dengan skor 3,98. Komentar dan saran yang 
diberikan validator digunakan untuk merevisi LKPD. Perubahan-perubahan yang terjadi pada LKPD pada tahap ini secara keseluruhan terlihat pada bagian konten (isi) dan bahasa.

Tahap one-to-one, pelaksanaan one-to-one dilakukan bersamaan dengan tahap expert review. Uji coba pada tahap one-to-one dilakukan kepada tiga orang peserta didik kelas XI MAN 1 Lahat dengan inisil AJP, SE, dan AC. Peserta didik diminta mengerjakan LKPD, setelah mengerjakan LKPD, peserta didik mengisi angket dan memberikan komentar dan saran mereka setelah menggunakan LKPD berbasis Inkuiri Terbimbing. Komentar dan saran ketiga peserta didik tersebut digunakan untuk kebutuhan revisi. Perubahan-perubahan yang terjadi pada tahap ini terlihat pada bagian konten (isi) dan bahasa. Angket kepraktisan yang mereka isi digunakan untuk mengetahui tingkat kepraktisan LKPD pada tahap ini. Berdasarkan hasil analisis, LKPD berbasis Inkuiri Terbimbing dinyatakan praktis dengan skor 3,87. LKPD yang telah melalui tahap expert review dan one-to-one disebut Prototype II.

Tahap small group, uji coba pada tahap small group dilakukan pada kelompok kecil yang terdiri dari 8 orang peserta didik kelas XI MAN 1 Lahat dengan inisial SPE, RTA, SA, NR, N, OP, AFS, dan YK. Peserta didik diminta untuk mengerjakan LKPD dalam bentuk Prototype II. Setelah mengerjakan LKPD, peserta didik mengisi angket serta memberikan komentar dan saran mereka setelah menggunakan LKPD berbasis Inkuiri Terbimbing pada kolom yang disediakan. Komentar dan saran yang mereka berikan digunakan untuk kebutuhan revisi prototype II menjadi prototype III. Secara keseluruhan perubahan pada LKPD di tahap ini hanya terjadi pada bagian bahasa. Angket kepraktisan yang mereka isi digunakan unuk mengetahui tingkat kepraktisan LKPD pada tahap ini. Berdasarkan hasil analisis angket kepraktisan LKPD yang diisi peserta didik, diperoleh skor kepraktisan 4,20 yang termasuk dalam kategori praktis. Berdasarkan hal tersebut LKPD berbasis Inkuiri Terbimbing materi Transformasi Geomeri dinyatakan praktis.

Tahap field test, Prototype III selanjutnya diujicobakan pada satu kelas XI MAN 1 Lahat. Kelas yang dipilih untuk diujicobakan adalah kelas XI IPA 1. Pada petemuan pertama dan kedua dilakukan ujicoba LKPD berbasis Inkuiri Terbimbing, peserta didik dibagi menjadi 6 kelompok yang terdiri dari 5-6 anggota. Pembelajaran dilakukan dengan tahap-tahap model pembelajaran Inkuiri Terbimbing yang terdiri dari 7 fase: 1) 
Orientasi; 2) Masalah; 3) Rumusan Masalah; 4) Hipotesis; 5) Pengumpulan data; 6) Uji Hipotesis; 7) Kesimpulan, yang disesuaikan dengan LKPD berbasis Inkuiri Terbimbing materi Transformasi Geometri yang digunakan. Pada akhir pembelajaran peserta didik diminta mengerjakan soal evaluasi 1 dan evaluasi 2 pada LKPD. Pada petemuan ketiga, peserta didik diberikan post-test untuk melihat keefektifan LKPD berbasis Inkuiri Terbimbing yang terdiri dari 5 soal memuat materi Translasi dan Refleksi untuk mengetahui keefektifan LKPD. Berdasarkan hasil analisis pengerjaan soal evaluasi pada LKPD dan post-test, hasil pengerjaan evaluasi 1 pada LKPD 1 dan evaluasi 2 pada LKPD 2 di atas nilai KKM yaitu > 60. Dan rata-rata nilai post-test pesera didik ialah 73,71 di atas nilai KKM yang termasuk kategori baik. Berdasarkan hal tersebut LKPD berbasis Inkuiri Terbimbing materi Transformasi Geomeri dinyatakan efektif.

Berikut beberapa perubahan yang terjadi pada produk pengembangan berdasarkan komentar dan saran yang diberikan pada tahap expert review (Prototype I ke prototype II).

Tabel 4. Tindakan Revisi Prototype I ke prototype II

\begin{tabular}{|c|c|}
\hline Sebelum Revisi & Sesudah Revisi \\
\hline Theme font di susah dibaca dan terlalu rapat & Theme font di ganti \\
\hline $\begin{array}{l}\text { dikembangkan dengan tujuan dapat } \\
\text { dan dapat membantu pendidik dalan } \\
\text { inkuiri Terbimbing yaitu orientasi, } \\
\text { hipotesis dan kesimpulan. Dalam Lk }\end{array}$ & \begin{tabular}{|l} 
LKPD berbasis lnkuiri Te \\
(Translasi dan Refleksi) dikem \\
peserta didik dalam memaham \\
pendidik dalam menyampaikan \\
lnkuiri Terbimbing yaitu orie \\
pengumpulan data, uji hipotesis \\
Terbimbing ini, peserta didik al
\end{tabular} \\
\hline Tidak terdapat penjelasan mengenai definisi translasi. & Definisi translasi ditambahkan \\
\hline Apakah bentuk dan ukuran benda-benda tersebut & $\begin{array}{l}\text { Translasi (pergeseran) adalah pemindahan su } \\
\text { dengan arah dan jarak tertentu. Contoh tr } \\
\text { kehidupan sehari-hari, seperti menggeser } \\
\text { pagar rumah. }\end{array}$ \\
\hline $\begin{array}{l}\text { Menggeser meja dan membuka/menutup pagar ry } \\
\text { kehidupan sehari-hari. Dapatkah kalian menyebutt }\end{array}$ & f. Berdasarkan hal tersebut, dapatkah kalian \\
\hline Gambar alat dan bahan tidak & Gambar alat dan bah \\
\hline
\end{tabular}




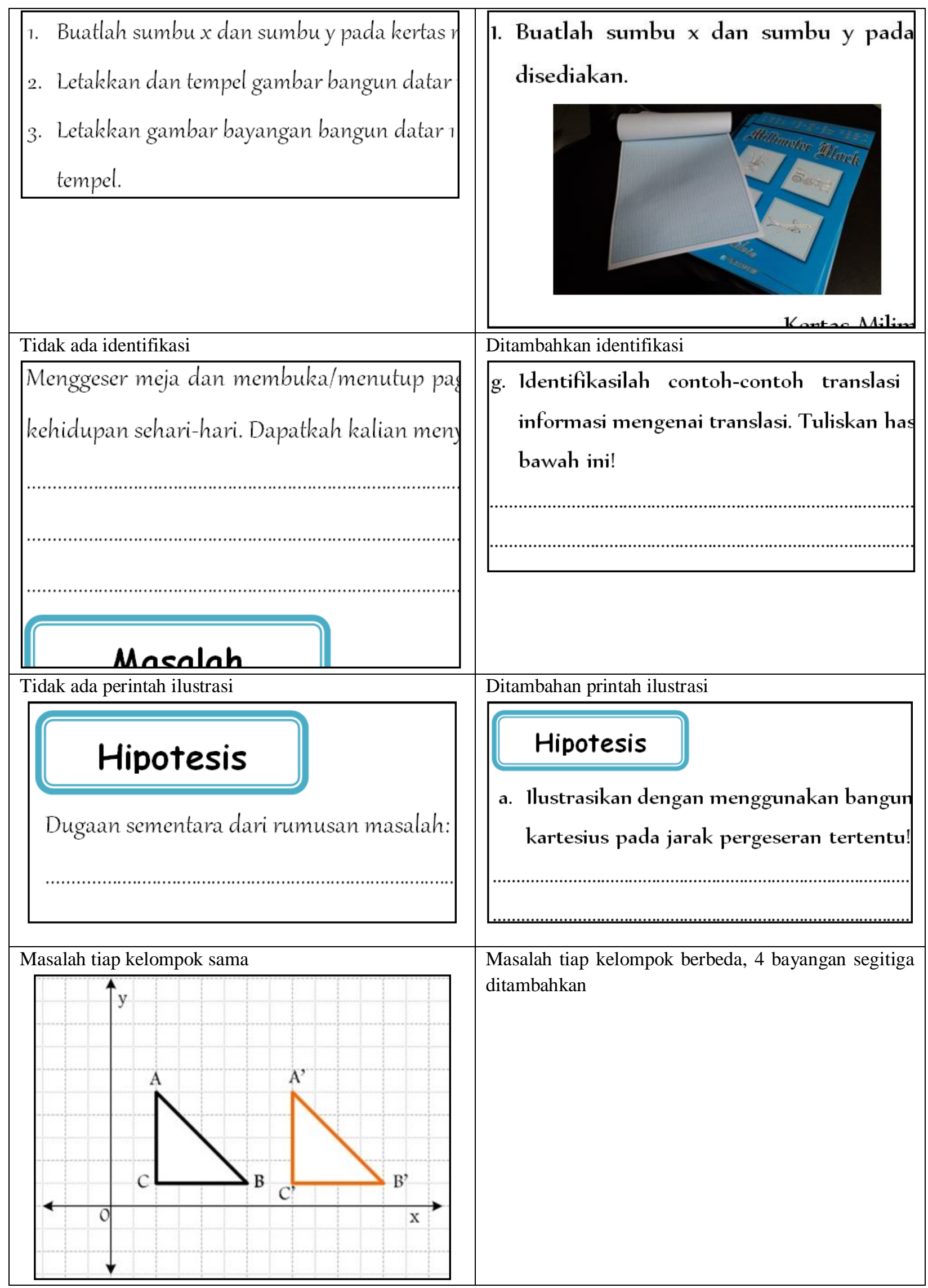




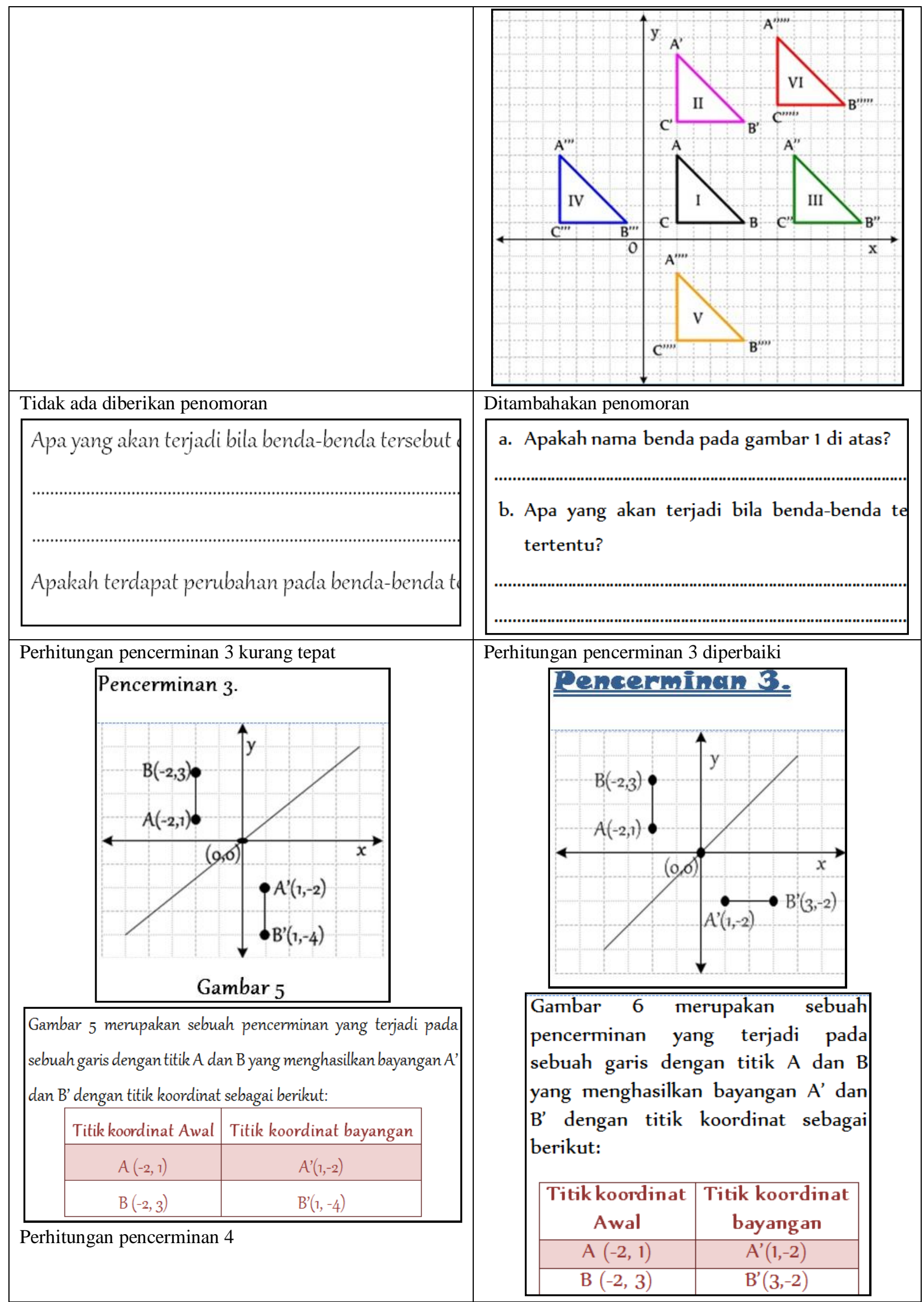




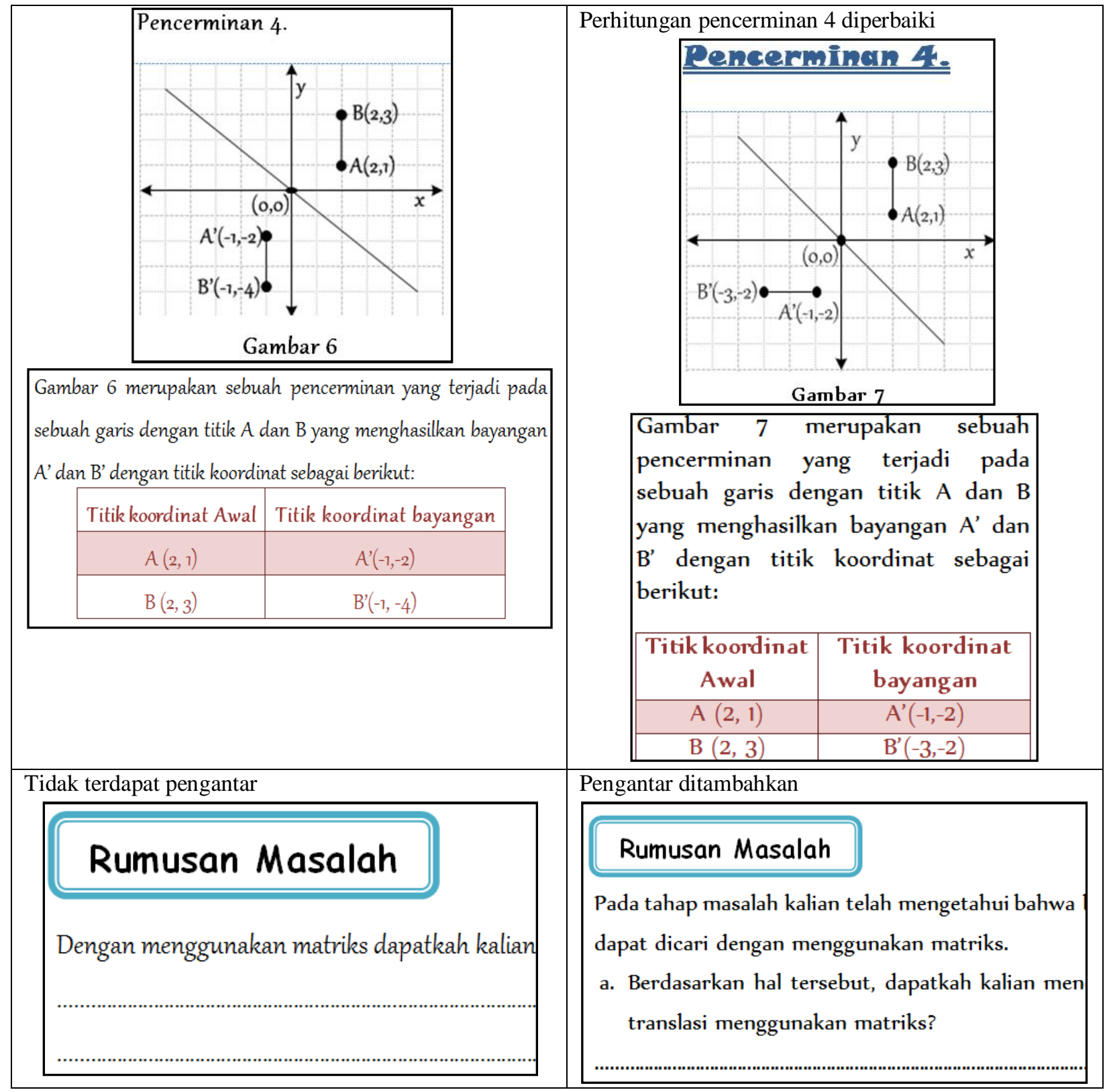

Setelah melakukan perbaikan berdasarkan komentar dan saran yang diberikan ahli/pakar pada tahap expert review, peserta didik pada tahap one-to-one dan small group serta analisis lembar walkthrough, angket dan tes maka LKPD berbasis Inkuiri Terbimbing materi Transformasi Geomeri dinyatakan valid, praktis dan efektif.

\section{SIMPULAN DAN SARAN}

Berdasarkan hasil penelitian yang dilakukan diperoleh kesimpulkan bahwa langkah-langkah pengembangan LKPD berbasis Inkuiri Terbimbing pada materi Transformasi Geometri di MAN 1 Lahat meliputi 2 tahap: (1) Tahap Preliminari yang terdiri dari tahap persiapan dan pendesainan. Pada tahap persiapan, peneliti melakukan 
analisis peserta didik di MAN 1 Lahat, kurikulum yang digunakan di MAN 1 Lahat dan analisis materi. Tahap pendesainan, peneliti mendesain sendiri LKPD berbasis Inkuiri Terbimbing, dengan memuat sintas Inkuiri Terbimbing (orientasi, masalah, rumusan masalah, hipotesis, pengumpulan data, uji hipotesis dan kesimpulan) di dalam LKPD. Pada tahap ini LKPD berbentuk prototype awal. (2) Tahap Prototyping menggunakan alur formative evaluation yang terdiri dari tahap self evaluation, expert review, one-toone, small group dan field test.

Berdasarkan prosedur tersebut, LKPD dinyatakan valid, praktis dan efektif. Pada tahap expert review LKPD memenuhi kriteria valid dengan skor kevalidan keseluruhan 4,07. Pada tahap one-to-one yang telah dilakukan diperoleh skor kepraktisan 3,87 dengan kriteria praktis dan pada tahap small group yang telah dilakukan diperoleh skor kepraktisan 4,20 dengan kriteria praktis serta efektif dengan rata-rata skor 73,71 yang memenuhi kriteria baik di atas nilai KKM dan pengerjaan LKPD semua peserta didik kelas XI IPA 1 MAN 1 Lahat di atas nilai KKM. Adapun saran bagi peneliti selanjutnya adalah dilakukan pengembangan bahan ajar Matematika berbasis Inkuiri Terbimbing untuk materi yang lainnya agar diperoleh bahan ajar dalam pembelajaran Matematika yang lengkap, dilakukan perencanaan yang sangat matang terutama dalama pemilihan materi karena tidak semua materi pada mata pelajaran Matematika dapat menggunakan model pembelajaran Inkuiri Terbimbing.

\section{DAFTAR PUSTAKA}

Arikunto, S. 2013. Dasar-dasar Evaluasi Pendidikan. Jakarta: Bumi Aksara.

Dewi, Narni Lestari. 2013. Pengaruh Model Pembelajaran Inkuiri Terbimbing Terhadap Sikap Ilmiah dan Hasil Belajar IPA. Jurnal Pendidikan dasar, 3(1).

Hartono, Rudi. 2013. Ragam Model Mengajar yang Mudah Diterima Murid. Jogyakarta: DIVA Press.

Jauhar, Mohammad. 2011. Implementasi PAIKEM dari Behavioristik sampai Kontruktivitis Sebuah Pengembangan Pembelajaran Berbasis CTL. Jakarta: Prestasi Pustakarya.

Lindawati, Sri. 2011. Pembelajaran Matematika Dengan Pendekatan Inkuiri Terbimbing Untuk Meningkatkan Kemampuan Pemahaman dan Komunikasi Matematis Siswa Sekolah Menengah Pertama. Jurnal Pendidikan, 2(2): 16-29. 
Ogle, Gwendolyn J. 2002. Towards A Formative Evaluation Tool. disertasi. Blacksburg : Fakultas Virginia Polytechnic Institute dan

State University.

Permendikbud. PP nomor 22 tahun 2016 tentang Standar Proses Pendidikan Dasar dan Menengah. Jakarta: Permendikbud.

Prastowo, Andi. 2014. Pengembangan Bahan Ajar Tematik. Jakarta. Kencana Prenadamedia Group.

Tessmer, Martin. 1998. Planning and Conducting Formative Evaluations. Philadelphia London: Kogen Page.

Trianto. 2010. Mendesain Model Pembelajaran Inovarif-Progesif. Jakarta: Kencana.

Winarsi, Oktavia. 2014. "Pengaruh Pemanfaatan Lembar Kerja Siswa (LKS) Terhadap Kemandirian Belajar Dan Prestasi Belajar Pendidikan Kewarganegaraan Siswa Kelas VIII SMP Negeri 3 Tempel". (http://eprints.uny.ac.id/ 22214/5/1.HALAMAN\%20 DEPAN.pdf, diakses pada 22 Oktober 2016).

Widoyoko, E.P. 2013. Teknik Penyusunan Instrumen Penelitian. Yogyakarta: Pustaka Belajar. 